\section{Angiotensin II: immunohistochemical study in Sardinian pterygium}

\author{
P. Demurtas, ${ }^{1}$ M. Corrias, ${ }^{1}$ I. Zucca, ${ }^{2}$ \\ C. Maxia, ${ }^{1}$ F. Piras, ${ }^{1}$ P. Sirigu, ${ }^{1}$ M.T. Perra ${ }^{1}$ \\ 'Department of Biomedical Sciences, \\ Medical School, University of Cagliari \\ ${ }^{2}$ Department of Surgical Science, Eye \\ Clinic, University of Cagliari, Italy
}

\section{Abstract}

The Angiotensin II (Ang II) is the principal effector peptide of the RAS system. It has a pleiotropic effect and, beside its physiological role, it has the property to stimulate angiogenesis and activate multiple signalling pathways related to cell proliferation. The purpose of the study was to determinate the Ang II expression and localization in Sardinian pterygium and normal conjunctiva by immunohistochemistry, and its possible involvement in the development and progression of the disease. Twentythree pterygiums and eleven normal conjunctiva specimens obtained from Sardinian patients, were processed for paraffin embedding and assessed for the immunohistochemical revelation of Ang II. Significant Ang II expression was identified in pterygium and conjunctiva. Particularly, thirteen pterygium specimens $(\mathrm{n}=13)$ displayed exclusively moderate to strong nuclear staining; some specimens $(n=5)$ showed exclusively a moderate cytoplasmic immunoreactivity, and few specimens $(n=2)$ displayed moderate to strong immunoreactivity in both cytoplasm and nucleus. Only 3 specimens were negative. Statistical significance difference in respect of nuclear and cytoplasmic localization was observed between normal conjunctiva and pterygium $(\mathrm{P}=0.020)$. The results showed a predominant intranuclear localization of Ang II in pterygium epithelial cells, in spite of conjunctiva that mainly showed cytoplasmic localization. These findings suggest a possible role for Ang II in the development and/or progression of pterygium mediated by the activation of local RAS system.

\section{Introduction}

The renin angiotensin system (RAS) is one of the most studied physiological systems in humans. It is well known as major actor in the regulation of cardiovascular homeostasis, maintaining electrolyte balance, body fluid vol- ume, and arterial pressure, through the production of aldosterone. ${ }^{1}$ The angiotensin II (Ang II) is the principal effector peptide of the RAS system. It has a pleiotropic effect and, in addition to its well-known physiological role, it is implicated in the development of cardiac, vascular and renal pathologies. ${ }^{2}$ Studies showed the property by Ang II to stimulate angiogenesis ${ }^{3}$ and activate multiple signalling pathways related to proliferation, including protein kinase C (PKC), ${ }^{4}$ mitogen-activate protein kinase (MAPK), ${ }^{5}$ and JAK II-STAT3. ${ }^{6}$ Moreover, synergically with its receptor $\mathrm{AT}_{1}$, it can act as trigger for the activation of phosphatidylinositol 3 (PI3)-kinase/Akt, ${ }^{7}$ which plays a pivotal role in a wide range of cellular processes, including cellular motility and cellcycle progression. ${ }^{8}$ Furthermore, studies from Nagai and co-workers, ${ }^{9}$ have demonstrated that Ang II enhances the vascular endothelial growth factor (VEGF) and is implicated in recruiting inflammatory cells by inducing chemokines and adhesion molecules. Novel studies have demonstrated that Ang II is also implicated in the growth of solid tumor cells, such as gastric, ${ }^{10}$ breast,${ }^{11}$ ovarian, ${ }^{12}$ and pancreatic cancer cells..$^{13}$

In these last decades has raised the hypothesis that tissue-specific RAS system may exist. It would act independently from circulating RAS in different tissues, as demonstrated in the eye. ${ }^{14,16}$ The local system may be characterized by the presence of some RAS components inside the cell and by the synthesis of Ang II in the intracellular compartments. However, to date this hypothesis is still matter of debate. ${ }^{1}$ Ang II and its main receptors $\mathrm{AT}_{1}$ and $\mathrm{AT}_{2}$ were found in distinct intracellular regions. ${ }^{15}$ Within the kidney, several groups showed a high density of Ang II in the nuclear fraction of both cortical and medullary areas in rat. ${ }^{16-18} \mathrm{Li}$ and Zhuo ${ }^{18}$ also demonstrated that the activation of Ang II-AT ${ }_{1}$ receptor axis modulates the expression of different mRNA transcripts involved in some pathological panels mediated by Ang II, such as monocyte chemoattractant protein, transforming growth factor and sodium hydrogen exchange (NHE3). Other emerging studies showed the intracellular localization of some pivotal components of the RAS, particularly the three principal AT receptor subtypes in the nucleus. ${ }^{1,19-21}$ Immunoreactive Ang II has been found in the inner membrane of the mitochondria of mouse proximal tubules and myocyte ${ }^{22}$ as well as in nuclear fraction of isolated rat cardiomyocytes. ${ }^{23}$

In the present study, we investigated the presence and localization of Ang II in pterygium, an ocular surface lesion associated with chronic UV exposure. ${ }^{24}$ For long time considered a simple degenerative lesion, pterygium is now accepted as a distorted wound-healing response and dysregulated cell proliferation
Correspondence: Dr. Cristina Maxia, Department of Biomedical Sciences, Cittadella Universitaria, University of Cagliari, SS 554, 09042 Monserrato (CA), Italy.

Tel. +39.070 .6754004 - Fax: +39.070 .6754003 .

E-mail: cmaxia@unica.it

Key words: Renin-angiotensin system (RAS), angiotensin II (Ang II), intracellular, immunohistochemistry.

Acknowledgments: the authors thank Mr. Massimo Annis and Mrs. Maria Itala Mosso for their skilful technical assistance. This study was supported by Grant from the Fondazione Banco di Sardegna, Italy, by Regione Autonoma della Sardegna within the project Master and Back 2008 and by University of Cagliari (Research Grant to PD), Italy.

Received for publication: 23 May 2014.

Accepted for publication: 2 July 2014.

This work is licensed under a Creative Commons Attribution NonCommercial 3.0 License (CC BYNC 3.0).

(C) Copyright P. Demurtas et al., 2014

Licensee PAGEPress, Italy

European Journal of Histochemistry 2014; 58:2426 doi:10.4081/ejh.2014.2426

disease. ${ }^{25}$ It is characterized by inflammatory features, rich vasculature, and extracellular matrix remodelling. ${ }^{26}$ Anti-apoptotic mechanisms, ${ }^{27}$ cytokines ${ }^{28}$ growth and angiogenic factors, ${ }^{29}$ and viral infections ${ }^{30-32}$ have been proposed as causative agents in its pathogenesis. Focusing on the pterygium features, and based on our previous study where we demonstrated the presence of the angiotensin converting enzyme (ACE) in pterygium, ${ }^{14}$ we aimed to investigate the presence of Ang II in bioptic pterygium samples. We hypothesized that a different Ang II localization/expression in pterygium, compared with normal conjunctiva, may be related to tissue-specific RAS system activation.

\section{Materials and Methods}

\section{Immunohistochemistry}

The study protocol for the use of human subjects in research was approved by the Human Research Ethics Committee of the Medical School, University of Cagliari, Italy. Patients with pterygium were admitted and treated at the Department of Surgical Science, Eye Clinic, University of Cagliari, Italy, while normal bulbar conjunctiva specimens were obtained from healthy donors undergoing strabismus surgery. 
Twenty-three pterygium specimens and eleven conjunctiva specimens were processed for paraffin embedding. Demographic information on these patients is recorded in Table 1. After surgery, tissue fragments were fixed in formalin for at least $18 \mathrm{~h}$. After fixation, tissues were washed in phosphate-buffered saline (0.1M PBS; pH 7.4) and processed. Paraffin-embedded serial sections (5 $\mu \mathrm{m}$ thick) were assessed for Ang II expression by immunohistochemistry. Briefly, sections were deparaffinized in xylene, rehydrated in a graded alcohol series and then equilibrated in PBS. Antigen retrieval was performed by citrate buffer $(0.01 \mathrm{M}$; $\mathrm{pH} 6)$ at $95^{\circ} \mathrm{C}$. Prior to incubation in the primary antibody, endogenous peroxidase activity was quenched with a solution of hydrogen peroxide $3 \%$ in $100 \%$ methanol for $20 \mathrm{~min}$. Then, the sections were incubated for 45 min with $5 \%$ skim milk solution to block non-specific sites. Sections were incubated over night at $4^{\circ} \mathrm{C}$ in rabbit primary antiserum polyclonal antibody to Ang II (1:100; Novus Biological, Littleton, CO, USA), and $30 \mathrm{~min}$ in anti-mouse peroxidase conjugated antibody (1:200, Chemicon International, Billerica, MA, USA) as secondary antiserum. 3,3'diaminobenzidine (DAB) was used as final chromogen. Archival autoptic human kidney paraffin embedded specimen was used as positive control, while negative controls included omitting the primary antibody and isotype control. All sections were counterstained in haematoxylin and mounted in Entellan mounting medium (Merck KGaA, Darmstadt, Germany). Each section was viewed by two investigators, taking into account the location (cytoplasmatic and nuclear) and intensity of Ang II staining. Experiments were conducted in triplicate. Positive cells were obtained by counting manually in ten random fields at $400 \mathrm{X}$. The cut-off was set at $60 \%$ of positive cells per field.

\section{Statistical analysis}

Statistical analyses were performed using the SPSS Statistical Package for Social Science, version 15.0 (SPSS Inc., Chicago, IL, USA). The difference of Ang II expression between primary and recurrent or nasal and temporal specimens, and the correlation of this protein with the clinicopathological variables, such as sex or age, were assessed by Fisher's exact test. All tests were two-tailed and P-values less than 0.05 were considered to be statistically significant.

\section{Results}

The results are summarized in Table 2 . Significant Ang II expression was identified in pterygium and normal conjunctival epithelial cells (Figure 1). In conjunctiva, six specimens showed strong cytoplasmatic immunoreaction for Ang II (Figure 1A). Two samples showed moderate to strong immunoreaction in both cytoplasmatic and nuclear compartment (Figure 1B). Only one sample displayed strong nuclear immunoreactivity (data not shown). In regard to pterygium, a high number of pterygium specimens $(n=13)$ displayed exclusively moderate to strong nuclear staining (Figure 1C). On the other hand, some specimens $(n=5)$ showed exclusively a moderate cytoplasmatic immunoreactivity (Figure 1D). Furthermore, few specimens $(\mathrm{n}=2)$ displayed moderate to strong immunoreactivity in both cytoplasm and nucleus (Figure 1E). Occasionally, some sections showed immunopositive leukocytes-like cells $(n=3)$ in the stroma and within the vessels (Figure 1F, arrows). No immunoreactivity developed in conjunctiva or in pterygium when incubated without a primary antibody and/or isotype control (Figure 1H). The kidney section showed strong immunoreactivity for Ang II in the cytoplasm and membrane of proximal renal tubules cells (Figure 1G).

Table 1. Demographic information for the pterygium and normal conjunctiva specimens.

$\begin{array}{lcc}\text { Characteristic } & \begin{array}{c}\text { Pterygium } \\ (\mathrm{n}=23)\end{array} & \begin{array}{c}\text { Normal conjunctiva } \\ (\mathrm{n}=11)\end{array} \\ \begin{array}{l}\text { Baseline mean age (SD) } \\ 52.9( \pm 11.98)\end{array} & 49.76( \pm 9.43) \\ \text { Sex (\%) } & 12(52) & 6(54) \\ \text { Male } & 11(48) & 5(46) \\ \text { Female } & 13(7 / 6) & - \\ \text { Type of lesion (M/F) } & 10(5 / 5) & - \\ \text { Primary } & 11(6 / 5) & - \\ \text { Recurrent } & 12(7 / 5) & - \\ \text { Eye (M/F) } & & - \\ \text { Right } & 13(7 / 6) & - \\ \text { Left } & 10(5 / 5) & \\ \text { Location of the lesion (M/F) } & & \\ \text { Nasal } & & \\ \text { Temporal } & \end{array}$

M, male; F, female.

Table 2. Angiotensin II immunolocalization in pterygium and normal conjunctiva.

\begin{tabular}{lccc} 
Localivation & \multicolumn{3}{c}{ Specimens } \\
& Pterygium & Conjunctiva & P-value \\
Cytoplasmic & 5 & 6 & 0.038 \\
Nuclear & 13 & 1 & \\
\hline Nuclear and cytoplasmatic & 2 & 2 & \\
Negative & 2 & 2 & \\
Total & 22 & 11 &
\end{tabular}

\section{Statistical analysis}

Statistical significance difference in respect of nuclear and cytoplasmatic localization was observed between normal conjunctiva and pterygium $(\mathrm{P}=0.038)$, while no significant association was obtained between Ang II expression and nasal or temporal eye localization, primary or recurrent pterygium specimens, and clinical features such as age and sex $(P>0.05)$. Moreover, no correlation was found in temporal or nasal localization, clinical features, and between primary or recurrent pterygium and clinical features $(\mathrm{P}>0.05)$.

\section{Discussion}

The present study shows the expression and immunolocalization of Ang II in pterygium and normal conjunctiva. Significative immunolocalization was noted in normal and pathological sections. It is widely known that Ang II is a multifunctional bioactive octapeptide of the renin-angiotensin system that plays a fundamental role in vasoconstriction, controlling cardiovascular function and renal homeostasis. ${ }^{33}$ In our study we were able to detect Ang II in different cellular compartments, with 
notable differences between normal conjunctiva and pterygium. Our findings show a predominant nuclear immunolocalization of Ang II in most of the pterygium samples. Solely few pterygium specimens show a moderate cytoplasmatic immunostaining. Over the past two decades, has raised the hypothesis of local, tissue-specific, RAS system, that could act independently from circulating RAS. On this way, many authors, with different approaches, demonstrated local RAS systems. ${ }^{34-38}$ In 1971, Robertson and Khairallah ${ }^{39}$ demonstrated nuclear localization of Ang II in smooth and cardiac muscle cells. Later, other authors correlated the presence of intracellular/nuclear Ang II to different cellular mechanisms implicated in cell growth and proliferation ${ }^{2,40}$ and tumor growth, invasion, and angiogenesis. ${ }^{41-43}$

In view of these studies, we found a similar pattern in pterygium. Thirteen samples showed nuclear localization versus five samples that showed positive cytoplasmatic stain. This evidence led us to hypothesize a possible response by Ang II in the inflammatory/proliferative processes in pterygium mediated in the nuclear compartment. In fact, some studies reported the ability of Ang II to bind the chromatin, ${ }^{44,45}$ to modulate gene expression, and to mediate different mRNA transcripts. ${ }^{16}$ Recent discoveries showed Ang II inducing rapid synthesis of VEGF in proximal tubular epithelial cells (MCT), by stimulation of its mRNA translation. ${ }^{46}$ Moreover, it has been documented that Ang II regulates activity of several key mediators of injury, such as transforming growth factor- $\beta$ (TGF- $\beta$ ). ${ }^{47-49}$ This intranuclear Ang II immunoexpression lead us to hypothesize a similar pathway in pterygium. Moreover, in the present study we were able to detect Ang II staining also in leukocytes-like cells; previous studies on human monocytes revealed that they contain high amount of Ang II, which may be potentially released under different stimuli. ${ }^{50} \mathrm{~A}$ well-known pterygium feature is the leukocytes infiltration consisting predominantly of lymphocyte T cells. ${ }^{51}$ In consideration of this statement, it is reasonable to think that a potential release of Ang II from leukocites, in a chronic inflammation condition, could contribute to worsen the disease stage. All these evidences are reinforced by the results obtained from normal conjunctiva. Here we found a predominant epithelial cytoplasmatic staining. This leads to believe that in physiological conditions Ang II may basically play a role in the cytosol. Ang II microinjections on rat vascular smooth muscle cells have demostrated an increase cytosolic $\mathrm{Ca}^{2+}$ levels inducing both intracellular stores and $\mathrm{Ca}^{2+}$ influx..$^{52}$ This suggests a possible support function by Ang II to normal, physiological, cellular mechanism, ${ }^{1}$ postulated that actually intracellular RAS system, and particularly Ang II, may work in different ways under different conditions. In physiological condition the intracellular RAS may support the circulating RAS and, as proposed by Eggena et al., it may increase the local Ang II concentration by transcription rate of some RAS components when the Ang II concentration is low, or suppressing transcription when Ang II levels are high. ${ }^{53}$ To date we can not assert if the intracellular RAS is an independent regulation system, however our feeling is that it could represent a more accurate control mechanism to support local and circulating RAS. This hypothesis is supported by a study from Kalinyak and Perlman ${ }^{54}$ which stated that circulating Ang II concentration, in normal physiological conditions, is insufficient to induce the multiple responses attributed to Ang II.
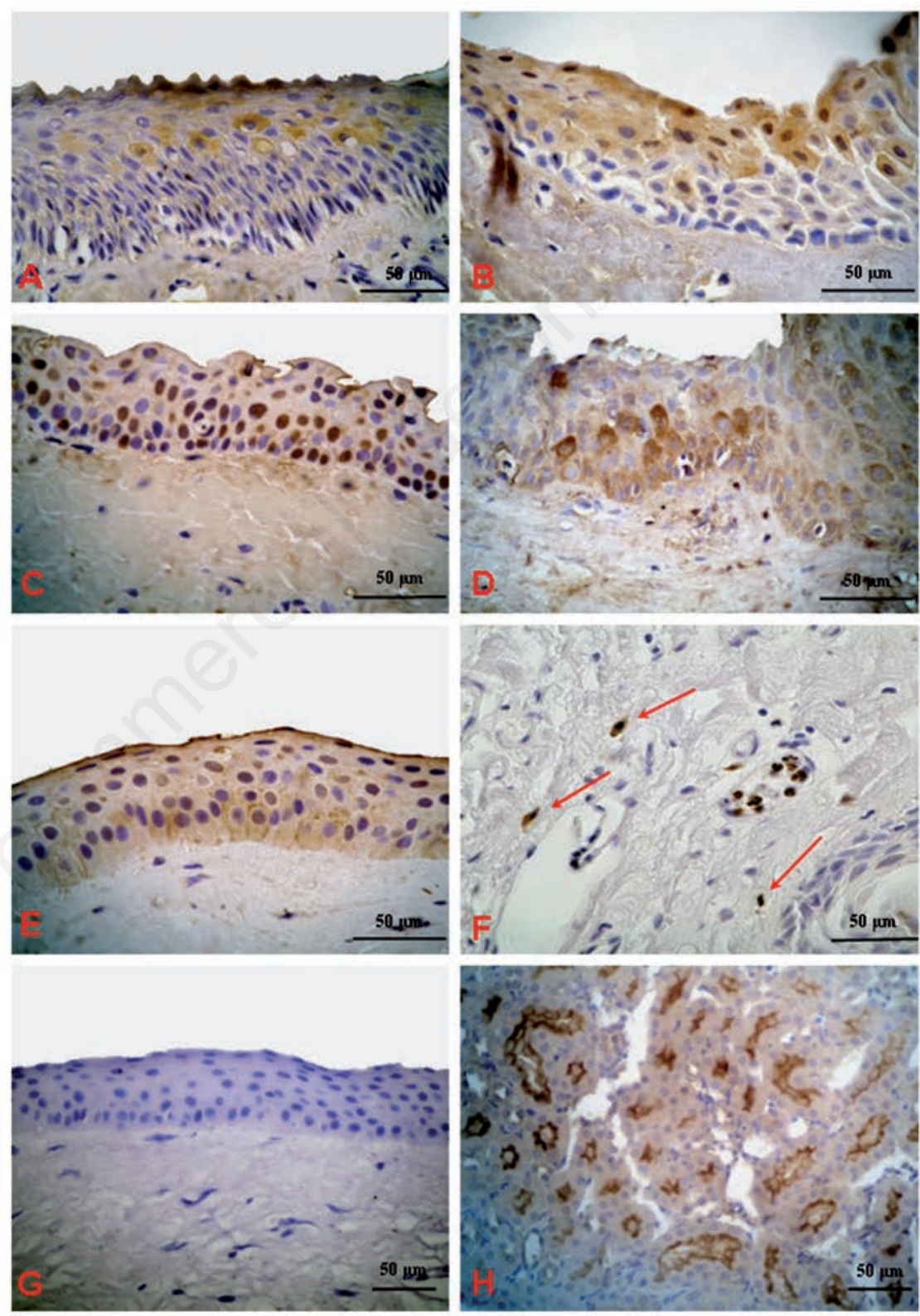

Figure 1. Immunohistochemical expression of angiotensin II (Ang II) in normal conjunctiva and pterygium. A) Positive immunoreactive staining is visible in the epithelial cells of normal conjunctiva in cytoplasm. B) Positive immunoreactive staining is visible in both cytoplasm and nuclear compartment. C,D,E) Nuclear, cytoplasmatic and both nuclear and cytoplasmatic positive immunostain to Ang II in pterygium epithelial cells, respectively. F) Ang II positive leukocytes-like cells are notable in blood vessels and in the stroma (arrows). G) Pterygium negative control does not display immunoreaction. H) Kidney shows specific immunostaining to Ang II. 
In conclusion, in this report we showed that pterygium epithelial cells exhibit Ang II in the nuclear compartment. Intranuclear localization could be attributable to the gene expression modulator role played by Ang II in pathological condition. Moreover, positive Ang II leukocytes-like cells in pterygium suggest a possible role due to the release of Ang II in pterygium. This study represents a tip of the iceberg and further studies will be needed to better clarify the intracellular role of Ang II in pterygium.

\section{References}

1. Kumar R, Singh VP, Baker KM. The intracellular renin-angiotensin system: a new paradigm. Trends Endocrinol Metab 2007; 18:208-14.

2. Baker KM, Kumar R. Intracellular angiotensin II induces cell proliferation independent of AT1 receptor. Am J Physiol Cell Physiol 2006;291:995-1001.

3. Carbajo-Lozoya J, Lutz S, Feng Y, Kroll J, Hammes HP, Wieland T. Angiotensin II modulates VEGF-driven angiogenesis by opposing effects of type 1 and type 2 receptor stimulation in the microvascular endothelium. Cell Signal 2012; 24:1261-9.

4. Greco S, Muscella A, Elia MG, Salvatore P, Storelli C, Mazzotta A, et al. Angiotensin II activates extracellular signal regulated kinases via protein kinase $\mathrm{C}$ and epidermal growth factor receptor in breast cancer cells. J Cell Physiol 2003;196:370-7.

5. Emura H, Ishiguro H, Nakaigawa $\mathrm{N}$, Nagashima Y, Miyoshi Y, Fujinami K, et al. Angiotensin II receptor blocker shows antiproliferative activity in prostate cancer cells: A possibility of tyrosine kinase inhibitor of growth factor. Mol Cancer Ther 2003;2:1139-47.

6. Bose SK, Gibson W, Giri S, Nath N, Donald CD. Angiotensin II up-regulates PAX2 oncogene expression and activity in prostate cancer via the angiotensin II type I receptor. Prostate 2009;69:1334-42.

7. Takahashi T, Taniguchi T, Konishi H, Kikkawa U, Ishikawa Y, Yokoyama M. Activation of Akt/protein kinase B after stimulation with angiotensin II in vascular smooth muscle cells. Am J Physiol 1999; 276:1927-34.

8. Zhao Y, Chen X, Cai L, Yang Y, Sui G, Fu S. Angiotensin II/angiotensin II type I receptor (AT1R) signaling promotes MCF-7 breast cancer cells survival via PI3kinase/Akt pathway. J Cell Physiol 2010; 225:168-73.

9. Nagai N, Oike Y, Noda K, Urano T, Kubota Y, Ozawa Y, et al. Suppression of ocular inflammation in endotoxin-induced uveitis by blocking the angiotensin II type 1 receptor. Invest Ophthalmol Vis Sci 2005; 46:2925-31.

10. Kinoshita J, Fushida S, Harada S, Yagi Y, Fujita H, Kinami S, et al. Local angiotensin II-generation in human gastric cancer: correlation with tumor progression through the activation of ERK1/2, NFkappaB and survivin. Int $\mathrm{J}$ Oncol 2009;34: 1573-82.

11. Muscella A, Greco S, Elia MG, Storelli C, Marsigliante S. Angiotensin II stimulation of Nap/KpATPase activity and cell growth by calcium-independent pathway in MCF-7 breast cancer cells. Endocrinology 2002; 173:315-23.

12. Suganuma T, Ino K, Shibata K, Kajiyama $\mathrm{H}$, Nagasaka T, Mizutani $\mathrm{S}$, et al. Functional expression of the angiotensin II type 1 receptor in human ovarian carcinoma cells and its blockade therapy resulting in suppression of tumor invasion, angiogenesis, and peritoneal dissemination. Clin Cancer Res 2005;11:2686-94.

13. Amaya K, OhtaT, Kitagawa H, Kayahara M, Takamura H, Fujimura T, et al. Angiotensin II activates MAP kinase and NF-kappaB through angiotensin II type I receptor in human pancreatic cancer cells. Int J Oncol 2004;25:849-56.

14. Demurtas P, Di Girolamo N, Corrias M, Zucca I, Maxia C, Diana A, et al. Immunohistochemical analysis of angiotensin converting enzyme in Sardinian pterygium. Histol Histopathol 2013;28:759-66.

15. Gwathmey TM, Alzayadneh EM, Pendergrass KD, Chappell MC. Novel roles of nuclear angiotensin receptors and signaling mechanisms. Am J Physiol Regul Integr Comp Physiol 2011;302:518-30.

16. Li XC, Zhuo JL. Intracellular ANG II directly induces in vitro transcription of TGF-1, MCP-1, and NHE-3 mRNAs in isolated rat renal cortical nuclei via activation of nuclear AT1a receptors. Am J Physiol Cell Physiol 2008;294:1034-45.

17. Licea H, Walters MR, Navar G. Renal nuclear angiotensin II receptors in normal and hypertensive rats. Acta Physiol Hungarica 2002;89:427-38.

18. Pendergrass KD, Averill DB, Ferrario CM, Diz DI, Chappell MC. Differential expression of nuclear AT1 receptors and angiotensin II within the kidney of the male congenic mRen2. Lewis rat. Am J Physiol Renal Physiol 2006;290:1497-506.

19. De Mello WC. Is an intracellular reninangiotensin system involved in control of cell communication in heart? J Cardiovasc Pharmacol 1994;23:640-6.

20. Filipeanu CM, Henning RH, De Zeeuw D. Intracellular Angiotensin II and cell growth of vascular smooth muscle cells. Br J Pharmacol 2011;132:1590-6.

21. Re R. Intracellular renin-angiotensin system: the tip of the intracrine physiology iceberg. Am J Physiol Heart Circ Physiol 2007;293:905-6.

22. Abadir PM, Foster DB, Crow M, Cooke CA, Rucker JJ, Jain A, et al. Identification and characterization of a functional mitochondrial angiotensin system. Proc Natl Acad Sci USA 2011;108:14849-54.

23. Tadevosyan A, Maguy A, Villeneuve LR, Babin J, Bonnefoy A, Allen BG, et al. Nuclear-delimited angiotensin receptormediated signalling regulates cardiomyocyte gene expression. J Biol Chem 2010; 285:22338-49.

24. Perra MT, Maxia C, Corbu A, Minerba L, Demurtas P, Colombari R, et al. Oxidative stress in pterygium: relationship between p53 and 8-hydroxydeoxyguanosine. Mol Vis 2006;30:1136-42.

25. Chui J, Coroneo MT, Tat LT, Crouch R, Wakefield D, Di Girolamo N. Ophthalmic pterygium: a stem cell disorder with premalignant features. Am J Pathol 2011;178: 817-27.

26. Chui J, Coroneo MT, Tat LT, Crouch R, Wakefield D, Di Girolamo N. Pathogenesis of pterygia: role of cytokines, growth factors, and matrix metalloproteinases. Prog Retin Eye Res 2004;23:195-228.

27. Tan DT, Tang WY, Liu YP, Goh HS, Smith DR. Apoptosis and apoptosis related gene expression in normal conjunctiva and pterygium. Br J Ophthalmol 2000;84:212-6.

28. Di Girolamo N, Kumar RK, Coroneo MT, Wakefield D. UVB-mediated induction of interleukin- 6 and -8 in pterygia and cultured human pterygium epithelial cells. Invest Ophthalmol Vis Sci 2002;43:3430-7.

29. Kria L, Ohira A, Amemiya T. Growth factors in cultured pterygium fibroblasts immunohistochemical and ELISA analysis. Graefes Arch Clin Exp Ophthalmol 1998;236:702-8.

30. Detorakis ET, Drakonaki EE, Spandidos DA. Molecular genetic alterations and viral presence in ophthalmic pterygium. Int $\mathrm{J}$ Mol Med 2010;6:35-41.

31. Piras F, Moore PS, Ugalde J, Perra MT, Scarpa A, Sirigu P. Detection of human papillomavirus DNA in pterygia from different geographical regions. $\mathrm{Br} \mathrm{J}$ Ophthalmol 2003;87:864-6.

32. Di Girolamo N. Association of human papilloma virus with pterygia and ocularsurface squamous neoplasia. Eye 2011;26: 202-11.

33. Dzau VJ. Circulating versus local reninangiotensin system in cardiovascular homeostasis. Circulation 1998;77:4-13.

34. Paul M, Poyan Mehr A, Kreutz R. Physiology of local renin-angiotensin sys- 
tems. Physiol Rev 2006;86:747-803.

35. Haller H, Park JK, Lindschau C, Meyer M, Menne J. Spotlight on renin: intrarenal renin-angiotensin system - important player of the local milieu. J Renin Angiotensin Aldosterone Syst 2006;7:122-5.

36. Sakai K, Sigmund CD. Molecular evidence of tissue reninangiotensin systems: a focus on the brain. Curr Hypertens 2005;7: $135-40$.

37. Leung PS, Carlsson PO. Pancreatic islet rennin angiotensin system: its novel roles in islet function and in diabetes mellitus. Pancreas 2005;30:293-8.

38. Goossens GH, Jocken JW, Blaak EE, Schiffers PM, Saris WH, van Baak MA. Endocrine role of the renin-angiotensin system in human adipose tissue and muscle: effect of beta-adrenergic stimulation. Hypertension 2007;49:542-7.

39. Robertson AL Jr, Khairallah, PA. Angiotensin II: rapid localization in nuclei of smooth and cardiac muscle. Science 1971;172:1138-9.

40. Baker KM, Chernin MI, Schreiber T, Sanghi S, Haiderzaidi S, Booz GW, et al. Evidence of a novel intracrine mechanism in angiotensin II-induced cardiac hypertrophy. Regul Pept 2004;120:5-13.

41. Fujimoto Y, Sasaki T, Tsuchida A, Chayama K. Angiotensin II type 1 receptor expression in human pancreatic cancer and growth inhibition by angiotensin II type 1 receptor antagonist. FEBS Lett 2001;495:197-200.

42. Juillerat-Jeanneret L, Celerier J, Chapuis BC, Nguyen G, Wostl W, Maerki HP, et al. Renin and angiotensinogen expression and functions in growth and apoptosis of human glioblastoma. Br J Cancer 2004;90: 1059-68.

43. Kikkawa F, Mizuno M, Shibata K, Kajiyama $\mathrm{H}$, Morita T, Ino K, et al. Activation of invasiveness of cervical carcinoma cells by angiotensin II. Am J Obstet Gynecol 2004; 190:1258-63.

44. Re RN, Vizard DL, Brown J, Bryan SE. Angiotensin II receptors in chromatin fragments generated by micrococcal nuclease. Biochem Biophys Res Commun 1984;119:220-7.

45. Re R, Parab, M. Effect of angiotensin II on RNA synthesis by isolated nuclei. Life Sci 1984;34:647-51.

46. Feliers D, Duraisamy S, Barnes JL, GhoshChoudhury G, Kasinath BS. Translational regulation of vascular endothelial growth factor expression in renal epithelial cells by angiotensin II. Am J Physiol Renal Physiol 2005;288:521-9.

47. Kagami S, Border WA, Miller DE, Noble NA. Angiotensin II stimulates extracellular matrix protein synthesis through induc- tion of transforming growth factor- $\beta$ expression in rat glomerular mesangial cells. J Clin Invest 1994;93:2431-7.

48. Wolf G, Neilson EG. Angiotensin II induces cellular hypertrophy in cultured murine proximal tubular cells. Am J Physiol 1990; 259:F768-77.

49. Wolf G, Mueller E, Stahl RA, Ziyadeh FN. Angiotensin II-induced hypertrophy of cultured murine proximal tubular cells is mediated by endogenous transforming growth factor- $\beta$. J Clin Invest 1993;92: 1366-72.

50. Kitazono T, Padgett RC, Armstrong ML, Tompkins PK, Heistad DD. Evidence that angiotensin II is present in human monocytes. Circulation 1995;91:1129-34.

51. Hill JC, Maske R. Pathogenesis of pterygium. Eye 1989;3:218-26.

52. Haller H, Lindschau C, Erdmann B, Quass P, Luft FC. Effects of intracellular angiotensin II in vascular smooth muscle cells. Circ Res 1996;79:765-72.

53. Eggena P, Zhu JH, Clegg K, Barrett JD. Nuclear angiotensin receptors induce transcription of renin and angiotensinogen mRNA. Hypertension 1993;22:496-501.

54. Kalinyak JE, Perlman AJ. Tissue-specific regulation of angiotensinogen mRNA accumulation by dexamethasone. Biol Chem 1987;262:460-4. 